\title{
Realities and perspectives of adolescent mothers in their first pregnancy
}

\author{
Realidades e perspectivas de mães adolescentes acerca da primeira gravidez \\ Realidades y perspectivas de madres adolescentes acerca del primer embarazo
}

\section{Rita de Cássia Andrade Neiva Santos', Raimunda Magalhães da Silva'", Maria Veraci Oliveira Queiroz", Herla Maria Furtado Jorge ${ }^{\text {III, }}$ Aline Veras Morais Brilhante ${ }^{\text {III }}$ \\ ' Universidade Estadual do Ceará, Postgraduate Program in Public Health. Fortaleza, Ceará, Brazil \\ "Universidade Estadual do Ceará, Department of Nursing. Fortaleza, Ceará, Brazil. \\ I' Universidade de Fortaleza, Health Sciences Center. Fortaleza, Ceará, Brazil.}

How to cite this article:

Santos RCAN, Silva RM, Queiroz MVO, Jorge HMF, Brilhante AVM. Realities and perspectives of adolescent mothers in their first pregnancy. Rev Bras Enferm [Internet]. 2018;71(1):65-72. DOI: http://dx.doi.org/10.1590/0034-7167-2016-0444

Submission: 08-29-2016 Approval: 03-06-2017

\begin{abstract}
Objective: to understand the trajectory of adolescents regarding the first pregnancy, contemplating realities and perspectives. Method: qualitative study, based on the Schütz theoretical framework, with 30 adolescents assisted in an outpatient clinic for adolescents in Fortaleza, Ceará, Brazil. From the narrative interviews carried out in the first semester of 2013, in the return for the first consultation of the puerperium, the communicative processes were identified, the central ideas and units of meanings expressed in the themes were abstracted: I was dating and became pregnant; realities and perspectives. Results: adolescents justified pregnancy through sexual drive and insufficient prevention; they narrated the fear faced, difficulties in motherhood and continuity of studies. The realities coexisted with the prospects of family members and partners helping to educate the child to achieve a different future from what they themselves experienced. Final considerations: adolescents experienced motherhood with ambivalent conflicts because they were young mothers, but they wanted to raise and educate their children, even those with minimal living conditions.
\end{abstract}

Descriptors: Adolescence; Pregnancy; Maternity; Health education; Qualitative Research; Family.

\section{RESUMO}

Objetivo: compreender a trajetória de adolescentes acerca da primeira gravidez, contemplando realidades e perspectivas. Método: estudo qualitativo, fundamentado no referencial teórico de Schütz, com 30 adolescentes assistidas em ambulatório para adolescentes em Fortaleza, Ceará, Brasil. Das entrevistas narrativas realizadas no primeiro semestre de 2013, no retorno da primeira consulta do puerpério, identificaram-se os processos comunicativos, abstraíram-se as ideias centrais e unidades de sentidos expressas nas temáticas: fui ficando e aconteceu a gravidez; realidades e perspectivas. Resultados: as adolescentes justificaram a gravidez pelo impulso sexual e prevenção insuficiente; narraram o medo enfrentado, dificuldades na maternidade e continuidade dos estudos. As realidades coexistiram com perspectivas de os familiares e companheiros ajudarem na educação do filho para obter um futuro diferente do que vivenciaram. Considerações finais: as adolescentes vivenciaram a maternidade com conflitos ambivalentes por serem mães jovens, mas desejavam criar e educar os filhos, mesmo aquelas com as mínimas condições de sobrevivência.

Descritores: Adolescência; Gravidez; Maternidade; Educação em Saúde; Pesquisa Qualitativa; Família.

\section{RESUMEN}

Objetivo: comprender la trayectoria de adolescentes acerca del primer embarazo, contemplando realidades y perspectivas. Método: estudio cualitativo, fundamentado en el referencial teórico de Schütz, con 30 adolescentes asistidas en ambulatorio para adolescentes en Fortaleza, Ceará, Brasil. De las entrevistas narrativas realizadas en el primer semestre de 2013, en el retorno de la primera consulta del puerperio, se identificó los procesos comunicativos, se abstrajeron las ideas centrales y unidades de sentidos expresas en las temáticas: fui quedando y sucedió el embarazo; realidades y perspectivas. Resultados: las adolescentes justificaron el embarazo por el impulso sexual y prevención insuficiente; narraron el miedo enfrentado, dificultades en la maternidad y continuidad de los estudios. Las realidades coexistieron con perspectivas de los familiares y compañeros ayudar 
con la educación del hijo para obtener un futuro diferente del que vivieron. Consideraciones finales: las adolescentes vivieron la maternidad con conflictos ambivalentes por ser madres jóvenes, pero deseaban criar y educar los hijos, mismo aquellas con las mínimas condiciones de sobrevivencia.

Descriptores: Adolescencia; Embarazo; Maternidad; Educación en Salud; Pesquisa Cualitativa; Familia.

\section{CORRESPONDING AUTHOR Herla Maria Furtado Jorge E-mail: herlafurtado@gmail.com}

\section{INTRODUCTION}

Adolescence is a phase of development with rapid biological, psychological and social changes ${ }^{(1)}$. This stage of the life cycle varies according to the social conceptions about the human and intergenerational relations of a given historical moment. In this movement, youth functions as a thermometer of possible social changes, being perceived as the generation responsible for transmitting values or breaking certain patterns ${ }^{(2)}$.

In Brazil, despite the deceleration in the growth rate of the young population, today the generation of adolescents and young people from 10 to 24 years of age is the largest in history, representing in the 2002 census approximately $30 \%$ of the population. There are a total of $35,287,882$ adolescents aged 10 to 19 years and 16,141,515 young people between the ages of 15 and $24^{(3)}$.

Among the transformations of adolescence, sexual maturation and acquisition of reproductive capacity occur, characterizing the development of an adult identity. In this transition period from childhood to adulthood, some adolescents initiate their sexual life, which may reflect on health problems and early pregnancy, with all the family, educational, and social repercussions, among other conditions of health risks, especially when they do not have appropriate protection ${ }^{(4)}$. There are several reasons for unprotected sexual behaviors among adolescents, such as multiple partners and alcohol use before intercourse $\mathrm{e}^{(4-5)}$.

Adolescent pregnancy has adverse social and health consequences as a result of their own development ${ }^{(1)}$. Young African women and refugees who experienced early motherhood in Australia faced challenges in dealing with increased responsibilities after the birth of the baby, managing the competitive demands of schooling, work, and caring for a newborn ${ }^{(6)}$. In Brazil, similar experiences are observed, in which the pregnant adolescent assumes responsibilities in the care of the child and herself, and other demands that compete with the role of woman and mother ${ }^{(7)}$.

It is added that there is rupture in the adolescents' personal projects, due to the pregnancy itself and the child's birth. It is common for the student to leave school and other environments of social interactions and face conflicts arising from the simultaneous changes inherent in adolescence and pregnancy. Sex education is therefore an indispensable action in the reduction of these vulnerabilities, and should not only focus on the preventive approach, but also promote dialogue with adolescents about the changes in the body during puberty, sociocultural issues and the relationship between genders ${ }^{(8)}$, based on health promotion programs.

In addition to the biological factors, teenage pregnancy should be approached in a subjective way, understanding the emotional aspects and social relations in the woman's experience, her reflections on the present and the future, to be considered in the construction of the adolescents' life project. Therefore, it is necessary to promote active listening and support for these adolescents.

Thus, this study approaches adolescents' narratives regarding their first pregnancy, focusing on realities and perspectives. Although the thematic of pregnancy in adolescence is extensive, and with several approaches ${ }^{(5-7,9-10)}$, gaps have been observed in this approach, since the various studies found portray various singularities of this phenomenon. Thus, it was outlined as an objective to understand the trajectory of adolescents in their first pregnancy, contemplating realities and perspectives.

\section{METHOD}

\section{Ethical aspects in conducting research}

The study complied with the ethical precepts of human research. The specificity of the adolescent participants was observed, and these, together with those responsible for them, were informed about the anonymity and the freedom to accept or refuse their participation, as well as other information included in the free and informed consent form signed by each participant and their legal guardian. The project was approved by the Research Ethics Committee. To preserve anonymity, the identification of adolescents was maintained by the letter " $\mathrm{A}$ " followed by a numeral chosen according to the sequential order of interviews.

\section{Theoretical-methodological reference}

A study based on the method of biographical narratives systematized by Schütz, which has a narrative structure conceived as the "organizing principle" of human experience and allows individuals to render intelligible those situations, events and actions occurring in the course of their lives ${ }^{(11)}$. Interviews and analysis of biographical narratives allow the researcher space for dialogue and reflection, as well as the ordering of the interviewees' own experiences, evaluating past, present and future perspectives expressed in the functions and sense of the plot. The narrative interview encourages and stimulates the reconstruction of lived events and within their social context $\mathrm{t}^{(12-13)}$

\section{Type of study}

A qualitative study using the method of biographical narratives with the objective of understanding how adolescents describe the experience of the first gestation, current experience and perspectives for the future. 


\section{Scenario and research participants}

The research was carried out from March to August 2013, in an outpatient clinic that serves pregnant adolescents in Fortaleza, Ceará, Brazil. Thirty adolescents between 12 and 16 years old, accompanied by adult relatives or the companion, were chosen intentionally. Adolescent mothers with an obstetric history of abortions, who gave birth to stillbirths, mothers with mental and/or neurological problems were excluded. The adolescents were interviewed in the first consultation up to 45 days postpartum, respecting the availability of each participant and after written consent. All the interviews were conducted in a suitable place, free of noise and by one of the researchers with experience in the care of pregnant teenagers and in qualitative research. The other researchers participated in the analysis, data validation and revision of the manuscript.

\section{Collection and organization of data}

Data collection took place through an interview, in which the autobiographical account occurred spontaneously and the narrator indicated the end of her story ${ }^{(14)}$. The adolescent mothers recounted freely, in a time between 40 and 50 minutes, the personal story about their first gestation. The researcher intervened when they concluded this phase (immanent question), with some clarifying questions: "I did not understand when you said [...] could you repeat [...]", among others. Subsequently, some exmanent questions related to the object under investigation were used: how do you feel about having dropped out of school? What do you think about child care? What do you think about your future and that of your child?

From the pre-analysis, the theoretical saturation was observed, at which point some redundancy or repetition was perceived, since the information extracted responded to the study objective ${ }^{13}$. Thus, the interviews that were being recorded in audio, transcribed in full and complemented with the observations of the field diary for the understanding of the phenomenon were finalized.

\section{Data analysis}

To understand the narratives, a symptomatic analysis of the data was conducted, starting with a textual presentation and a complete description of the sequence of these. The main formal indicators of narrative text structure are the marking elements that indicate the finalization of a presentation unit from which the next unit begins. These are highlighted as linking elements between the presentations of specific events (then, for, because, however, and so on); markers of temporal flow (still, already, already at that time, suddenly, and others) or markers related to the lack of plausibility and need for additional detailing (delayed pauses, sudden decrease in the level of narrative activity, autocorrection with interjections associated with the explanations) ${ }^{(14)}$.

The analysis began with the reading and re-reading of the information, formal analysis of the text, identifying the different communicative schemes (narration, description and argumentation). The sequence was maintained in each segment of the central narration and of other expressions from the later phases of the questions, that is, the immanent and exmanent issues. The descriptive dimensions were related to the events, values and feelings of the adolescents during the first pregnancy, a construction that involves complex web of the experiences permeated by meanings. Moreover, the argumentative dimensions refer to the legitimation of what is not accepted peacefully in history and the reflections of the lived experiences. They are abstract references, since they go beyond events, they express values, judgments and a whole generalized form of life wisdom ${ }^{(11)}$.

In the analytic abstraction, the researcher distances himself from the details observed and begins to reconstruct the biography as a whole, maintaining the sequence of the procedural structures of the experiences produced by the person in charge of the autobiography ${ }^{(14)}$. The interpretation of this proposal aims at a reconstruction of events and biographical processes of the narrator. Thus, the central ideas that gave origin to the sense units were highlighted; the following topics emerged from this organization: I was dating and the pregnancy happened; realities and perspectives narrated by adolescents.

\section{RESULTS}

The sociocultural characteristics of the adolescents showed that out of the 30 interviewees, $60 \%$ became pregnant in the age group of 12 to 14 years and $40 \%$ between 15 and 16 years. In all, 43\% began their sexual life between 12 and 13 years. The majority came from cities in the state of Ceará and were single, with no bond with the child's father (56.7\%). All the adolescents were students when they became pregnant and did not work, however $66.7 \%$ stopped studying. All were literate, and $76.6 \%$ of them attended elementary school without yet completing this level; $20 \%$ high school, again without completing this level; and $3.4 \%$ had completed Elementary School level. The majority, $76 \%$, reported having some kind of religion. The financial responsibility of the adolescents was linked to their parents (53.4\%); mother-in-law or father-in-law (16.5); grandparents (3.4\%); and companion (26.7\%).

\section{I was dating and became pregnant}

In their narratives, the adolescents constructed and presented concepts of themselves, of their worlds, of their theoretical and identity schemes, counting both for themselves and for their listeners. They brought from memory the lived reality and the "reasons of the pregnancy", referring to the awakening of sexuality:

I was dating secretly with my 14-year old neighbor [...] there it happened! I thought he was tall, handsome and I began to like him ... it was like a fancy [...]. (A1)

My stepfather's nephew went to my house a lot for the weekend, so I liked him and I started sleeping with him on the weekends, and then I had a desire and I slept with him several times. (A4)

Other narratives have demonstrated the culture of dating, sexual relationships evolving without proper protection:

[...] it was only the desire to have sex ... the desire to have it ... I did not want to get pregnant [...]. (A30) 
My boyfriend always said that if I did not have sex with him [...] he would look for another, he would have sex with another ... I let it go, I slept with him and it ended up happening. (A2)

I liked him, I was dying for him, and it ended up happening, I did not want to lose him [...]. (A24)

The adolescents who slept with their boyfriend or even when they had a longer relationship had sexual intercourse without the use of contraceptives and acknowledged to be a weakness or "disobedience" since they were aware of the risks of becoming pregnant:

I got myself pregnant for the rubbish of life, the disobedience to my parents [...] That's all [...] I had sex for the desire that was great [...], but I did not know of such consequences. (A26)

I got pregnant for love and irresponsibility, nothing motivated me to get pregnant, I was just dating [...] but I did not want to get pregnant, no. It's me who takes care of my house, my two brothers and my father, he is a widower. (A27)

Despite the information on safe sex and pregnancy prevention measures that permeate the lives of adolescents, many started their sex lives without using these resources, risking their own fate. The emotion of sexuality goes beyond the notion of contraception. In the narratives, the adolescents assumed these attitudes:

[...] it was crazy, it was a horny thing, a teenage passion. [...] I was not motivated to get pregnant, it just happened [...]. (A15)

It was without thinking, good sense was lacking, I liked him very much [...] I was dating secretely in my cousin's house [...]. (A20)

I was too lazy to go to the clinic to get a condom and the pill. My mother warned me, but I did not care. He did not care [...]. It was just the urge to grab me. I knew everything that could happen, but it happened [...]. (A28)

The adolescents reported inexperience and justified the reasons for the pregnancy; even those who used contraceptives, did so in an irregular way:

I forgot one day to take the contraceptive and I got pregnant. I studied a lot, so I did not want to get pregnant, I was finishing the secretarial course. (A12)

Since I was 13, I wanted to have a child, but I did not plan it. I always took an injection to avoid pregnancy, but every now and then I forgot. (A23)

He asked a lot for sex with me, but he did not want condoms at all, and I, tested my luck, accepted. I should have been stronger, more prepared, but now it's no use, what I've done is done [...]. (A3)
Forgetting to regularly use contraceptives among adolescents is real, but some coexisted with the fear of their parents discovering the onset of sexual intercourse, others were unaware of the proper use of contraceptive methods, and faced difficulties in accessing planning and prevention methods. Among the reasons narrated by the adolescents, they went through difficulties and/or laziness:

I did not want to get pregnant, but since I was together with her father and lived in the interior, it was very difficult to go to the health post. I did not get pregnant by wanting to, it was due to the difficulties [...]. (A9)

I was too lazy to go to the clinic to get a condom and a pill. My mother warned me, but I did not care, no. I couldn't care less. (A29)

In addition, there are also difficulties in communication and dialogue between parents and educators. The narratives referred to the reality that compromised the responsibility of the school, while the adolescent felt guilty for their attitude of assuming the relationship without protection and how she experienced the fear that the mother discovered the use of contraceptives:

I got pregnant because of a lack of knowledge and support, and they did not give me pills or condoms at school, no; my friends would tell me to take the pill, but I could not take it and I was still afraid that my mother would discover [...] she would mess with my things and see the medicine. I was afraid of getting pregnant ... but it happened. (A10)

I just did not use a pill because I was afraid my mother would find out, I was afraid of getting fat, everyone said that the pill makes you fat ... I did not plan anything, it was because I did not use a condom, really. (A15)

The difficulties reported in contraception showed common realities around the lives of adolescents in society and referred to the debates about the responsibility of the school, the family and health professionals in the sexual support and education of adolescents, but mainly in the absence of their attitude towards pregnancy prevention.

\section{Realities and perspectives narrated by the adolescents}

The individual trajectories of the adolescents were inserted in a social reality, constructed and modified by the everyday phenomena. They learnt from the experiences of their first pregnancy; the situations faced with fear of social and family reactions and the prospects for the future.

[...] I will not be able to study again [...]. I'll leave studying for later. It changed everything, I have a son to raise [...]. (A1)

I do not know if I will study yet [...]. I do not think I'm going to have free time with study, no. (A15)

[...] one day I want to go back to school, but only when he grows up ... I cannot afford to pay someone to take care of him. (A2) 
The adolescents reported abandoning school due to financial difficulties, lack of family support or absence of the child's father. Thus, they would have to dedicate themselves and accompany the development of the child, assuming responsibilities in the care of the child, since many did not count on this support:

I really have to take care of my son, even though I live with my mother-in-law. (A3)

[...] because there is no one to take care of him, I always relied on my mother, now I have to take care of him. (A10)

[...] I had many difficulties with money in the pregnancy, I did not even know how I would take care of this child. I have been very desperate, because I am still young and I do not know anything about caring for the child [...]. (A21)

[...] I want to find a job, I have no more mind to study, no, and I need money. (A9)

In the experiences of these teenagers, dropping out of school, due to maternal responsibilities, is a reality that represents an interruption in life projects such as schooling and personal development. However, caring for the child was seen as daily learning, a search for overcoming and affirming their condition of mother. Support from the family was essential so that the young mothers learned to take care of their children and were attentive to their needs. The presence was very relevant of the mother, the sister or even the mother-in-law. Narratives show that adolescents conform with and take responsibility for caring for their child:

I'm going to continue my life taking care of my brothers, my house, my father [...] and now my son, now I have to take care of more people [...] I'll have to be more responsible. (A27)

While my mother works, I take care of her and my mother's house. (A25)

Encouraging some adolescents to care for their children seems to be associated with the responsibility of caring within their own family; having cared for other children prior to pregnancy. In this way, they felt satisfied in the role of mothers and presented a strong commitment with themselves, since they recognized motherhood and child care as a social role to play. However, they felt the need for paid work, to help the family and to acquire or maintain autonomy.

I'm going to work to support my son, I know I have to study, but I cannot now ... I have to work to help my father ... but it's difficult to get a job at my age [...] my boyfriend is also a minor (A1)

One day I also want to work to be able to support him (A28)

I want to work ... to get out of this house ... humiliation [mother-in-law's house] (A11)

I still work until now and the father of the child lives in his house and does not help at all (A13)
It was observed that among adolescents the financial problem was a challenge to be faced, which recognized limits for insertion into the formal labor market. The lack of perspectives and the withdrawal from school life bring uncertainties:

[...] only then will I think about studying and then go to work. I do not know if my boyfriend will support my son, no. (A26)

[...] I do not expect anything for my life ... I still have not planned anything for my future ... I do not have much financial stability ... I do not know what will become of me. (A6)

I have many challenges ahead, I stopped preparing for my future, I stopped studying and I cannot work ... I wanted a future for myself [...]. (A8)

The narratives conveyed the hopelessness and discouragement in resumption of life projects by linking the responsibility of generating and raising a child in adolescence with the uncertainty of a promising future. However, other accounts have shown the perspectives surrounding their child's life:

I do not want my son to be a young father, but it's his life. [...] I really want him to study to be independent [...]. (A2)

I want him to think only of studying and working ... I want him to think about his future [...]. (A30)

I only want him to be a father when he knows what he's doing and only when he can support himself, only after ... a lot of study. (A26)

The adolescents projected imaginary perspectives of the future, for their children, different from the trajectory they had followed; they intended to promote and secure a career or good job coming from the student project.

\section{DISCUSSION}

The sociocultural characteristics of the adolescents studied showed similar realities to another study carried out in Cuiabá, Mato Grosso, Brazil, in which all participants studied only in the public school system, four adolescents enrolled in high school and one in elementary school. Six had stopped school, two before and four after pregnancy; only one completed High School. None of them had paid work, and all of them took care of the child and depended financially on the partner or family ${ }^{(9)}$.

Among the variables of social insertion is the educational level, since the relation between study opportunities and social inclusion is indissociable ${ }^{(10)}$. The phenomenon of teenage pregnancy is one of the events that causes young Brazilians to have fewer work opportunities and a less dignified life. A recent study in Latin America reports that teenage motherhood reduces the number years of schooling, the chances of finishing high school, and continuing higher education. It is important to emphasize that among the most important reasons for young women in the Americas and Caribbean region 
not to attend school are domestic and maternal duties. However, among men, only $0.5 \%$ declared these reasons as the main cause for not attending an educational institution ${ }^{(15)}$. This shows the importance of guiding and helping adolescents (male and female), so that there are no breaks in schooling and they postpone maternity/paternity.

The analysis of the narratives of adolescents identified specific ways of experiencing the first pregnancy: the life trajectory when they assume affective and intimate relationships driven by physical attraction and sexual desires without reflecting on the consequences when there is no sexual protection between the couple. It is necessary to discuss with adolescents the differences about sex and sexuality, since this involves more than a representation of the body, our history, our customs and our affective relations. It is much more than sex, an eminently biological part of the body that allows people to reproduce ${ }^{(16)}$.

It is argued that recent changes in sexual customs in Brazil have introduced other forms of relationships among adolescents, such as "ficando" [literally "staying", in the sense of sleeping with or casual sex]. Dating is no longer a preparatory stage for conjugal life and has acquired a reality in itself, as a stage of affective and sexual experimentation for adolescents of both sexes ${ }^{(2)}$. In adolescence, the terms dating and ficando are part of sexuality and in this relationship sexual intercourse can occur without the use of contraceptives and unplanned pregnancy.

It is seen that, even with so much information circulating in the social environment of adolescents, they do not always use contraception in a continuous and agreed form with their partner. Therefore, it is necessary to identify adolescents' knowledge about the proper use of contraceptive methods: for them to be aware of the existing barriers to use; their intentions regarding reproductive planning; and even access to contraceptives. Studies with adolescents have shown unfavorable knowledge and attitudes towards contraception and warn that contraceptive methods should be used before sexual initiation. In addition, educational actions should awaken adolescents' practical knowledge of contraception ${ }^{(17-18)}$.

In this phase, in addition to instability in personality structure, households are bombarded daily by the media and adolescents are exposed to sexual stimuli in various social settings. Although the literature recognizes school as an important space for sexual and reproductive education ${ }^{(19)}$, adolescents demonstrate that they receive information about sexual and reproductive health, mainly through friends, the media and family ${ }^{(16-19)}$.

The biographical trajectory of the adolescents belonging to specific groups is permeated by obstacles inherent in the social, educational and developmental stages. The interviewees showed the immaturity in the relations with the partner and the lack of dialogue about reproductive planning; some hinted that pregnancy was unexpected, even without correct use of contraceptive methods. The findings corroborate other studies that observed the non-use of condoms and warn about health risks, in addition to early pregnancy ${ }^{(17,20)}$.

In view of the aforementioned facts, the dialogue about sexuality and pregnancy in the family and school environment is still a taboo and it seems that responsibility for sex education is lacking. Nevertheless, the school is the institution that most often advises adolescents about sexuality before sexual initiation, especially when compared to the family.

Public policies that integrate the institutional pillars responsible for this problem of teenage pregnancy are recommend$\mathrm{ed}^{(10)}$. In this sense, there are various political guidelines in Brazil that govern actions and strategies for the development of adolescents and young people, focused on risk reduction and health promotion, but the integration of sectors is a prerogative yet to be achieved ${ }^{(16)}$.

The school environment is a place for health promotion, such that education is an important tool to prevent unplanned pregnancy and sexually transmitted diseases among adolescents. When the school does not perform its role as promoter of sexual and reproductive health, there is an increase in the likelihood of unprotected sexual intercourse ${ }^{(16,20)}$.

The second category brings the experiences of the adolescents with the pregnancy, permeated by reflections on the current events and repercussions in the future, negative feelings from the interruption to their studies. Among the reasons for leaving school, they listed the symptoms of pregnancy, such as nausea, weight gain, mood swings and drowsiness, linked to greater commitment to the child, especially during breastfeeding. These experiences in fact lead to abandoning school ${ }^{(6-15)}$.

Maternity brings increased responsibilities, social recognition, and a sense of purpose to young mothers. Despite the positive aspects of motherhood, young African refugee women in Australia faced challenges that affected their lives, although they received support from their mothers, siblings and close friends, but rarely from the father of the baby and the community at large ${ }^{(5)}$. The social support network, especially in economically disadvantaged or socially vulnerable populations, favors subjective construction, identity organization and psychosocial development. The movement of this theme favors a healthy life along personal and social development ${ }^{(12)}$.

In this study, despite the difficulties, the adolescents expressed their desire to continue their studies, while others wished to begin paid work, thereby contributing to the family's income and bringing significance to their lives. The insertion of the young person into the workplace contributes to an increase in the family income and the young person begins to think in terms of their "life project". These are two overlapping and interdependent plans, the inner world of the adolescent and the interactions within the context of life, including significant people who are part of their personal universe. The study showed that the social construction of meanings about pregnancy-motherhood among pregnant adolescents finds a counterpoint to the dominant discourse of adolescent pregnancy as a problem, since they projected for themselves a social ideal of motherhood and family constitution, proof of femininity and greater power and autonomy. However, these gains have been overcome by difficulties, since they live in a context of restricted social opportunities ${ }^{(5)}$.

In the transition from youth to adult life, the first experience in the world of work occurs, when very young people face specific problems, such as the requirement for previous 
experience, and often requirements that involve training/ professionalization. Thinking about the future is an important protective factor, even if it is insufficient at the moment of practicing self-care related to the sexual and reproductive rights of adolescents ${ }^{(15)}$.

In view of this reality, there is a need to implement educational strategies integrating sectors such as health and education, making use of existing political guidelines, giving adolescents choices that favor personal and social development and envisioning the promotion of sexual and reproductive health.

\section{Limitations of the study}

The study presents limitations arising from being conducted in the return puerperal consultations; therefore, the contextual observations did not reach possibilities to evaluate other scenarios involving the socio-familiar structure of the pregnant adolescent. The need is also considered to include information from the perspective of the professionals who care for the pregnant adolescents. Thus, further investigations are recommended that capture these contexts and complementary information, enabling more discussions that could guide the sexual and reproductive care and education of adolescents.

\section{Contributions to the area of Nursing, health or public policy}

Possibilities for application of the theoretical methodological reference of autobiographical narrative are considered to understand the significance of this phenomenon, by establishing relations with the care and appreciation of the adolescents' subjectivity in their experience of pregnancy. It is believed that it will strengthen the nurses' performance in the furthering of educational actions with these young women, by overcoming traditional models, stimulating the expression of the subjects before the circumstances of early pregnancy with moments of care and health promotion.

\section{FINAL CONSIDERATIONS}

Seeking to understand the trajectory of adolescents during their first pregnancy, the narratives expressed experiences and fostered reasons, changes and realities resulting from this event. Participants engaged in intercourse without the use of contraceptives due to immaturity and stated that prior knowledge about sexuality and pregnancy prevention did not sustain protective attitudes; they demonstrated in many cases difficulties in accessing contraceptive methods and ineffectual care services, such as health, education and family resources.

The adolescents showed that, before pregnancy, they did not think about future projects and, in the current experience, their uncertainty was mainly due to low educational level and discontinuation of studies, because they imagined that they would face difficulties in starting work and helping the family financially. Faced with the adversities they experienced, perspectives emerged associated with overcoming these difficulties and self-assertion in the role of mother. Thus, they intended to take care of the child, to offer protection and to ensure they would not undergo the same trajectories of suffering, to which they themselves were submitted.

It was observed that the life of the adolescents was immersed in a wide context of social, educational and familial relations, besides the personal problems that prevented them from obtaining resources necessary for the protection of their unplanned pregnancy. The experiences of motherhood were lived with ambivalent conflicts because they were young mothers, but they wanted to raise and educate their children, even those with minimal living conditions. It is suggested that the facing of vulnerabilities and gestation in adolescents can be optimized by the work of professionals in the basic health units. These units are equipped with structural and human resources, providing the follow-up and guidance for these young women, essentially nurses carrying out the planning and execution of educational activities for adolescents, focusing on sexual and reproductive health; aspects recommended in the health policies that integrate primary care and schools.

In this aspect, it is underscored that in order to increase the opportunities for dialogue and autonomy of adolescents, it is essential to include parents, educators and health workers in an integrated project involving the health and education sectors, accompanying and stimulating them to engage in safe sex with the potential to reduce the incidence of unplanned pregnancy.

\section{REFERENCES}

1. World Health Organization (WHO). Health for the world's adolescents: a second chance in the second decade[Internet]. 2014 [cited 2015 Sep 01]. Available from: http://www.who.int/maternal_child_adolescent/documents/second-decade/en/

2. Brasil. Ministério da Saúde. Diretoria de Pesquisas. Coordenação de População e Indicadores Sociais. Pesquisa Nacional de Saúde do escolar: 2012. Ministério do Planejamento, Orçamento e Gestão[Internet]. Brasília: Ministério da Saúde; 2015 [cited 2014 Sep 01]. Available from: http://biblioteca.ibge.gov.br/visualizacao/livros/liv64436.pdf

3. Heilborn ML. Por uma agenda positiva dos direitos sexuais da adolescência. 2012 Psicol Online[Internet]. 2012 [cited 2016 Nov 30];24(1):57-68. Available from: http://www.scielo.br/pdf/pc/v24n1/05.pdf

4. Kempfer SS, Fraga SMN, Mafra TJ, Hoffman ACS, Lazzari DD. Contracepção na adolescência: uma questão de autocuidado. Rev Pesq: Cuid Fundam[Internet]. 2012[cited 2016 Nov 30];4(3). Available from: http://www.seer.unirio.br/index.php/cuidadofundamental/article/ view/1867/pdf_610.

5. Araujo NB, Mandú ENT. Construção social de sentidos sobre a gravidez e maternidade entre adolescentes. Texto Contexto Enferm[Internet]. 2015 [cited 2016 Apr 10];24(4). Available from: http://www.index-f.com/textocontexto/2015/241139p.php 
6. Watts MCNC, Liamputtong P, McMichael C. Early motherhood: a qualitative study exploring the experiences of African Australian teenage mothers in greater Melbourne, Australia. BMC Public Health [Internet]. 2015[cited 2016 Oct 15];15:873. Available from: https://www.ncbi.nlm.nih.gov/pmc/articles/PMC4566485/pdf/12889_2015_Article_2215.pdf

7. Soares LR, Cabero FV, Souto TG, Coelho RFS, Lacerda LCM, Matão MEL. Avaliação do comportamento sexual entre jovens e adolescentes de escolas públicas. Adolesc Saude [Internet]. 2015 [cited 2016 Apr 10];12(2):76-84. Available from: http://www. adolescenciaesaude.com/detalhe_artigo.asp?id = 504

8. Brilhante AV, Catrib AMF, Silva RM. Educação sexual na adolescência: como estratégia de promoção em saúde. Fortaleza: Edições UFC; 2014.

9. Araujo NB, Mandú ENT. Produção de sentidos entre adolescentes sobre o cuidado de si na gravidez. Interface[Internet]. 2016 [cited 2016 Jun 25];20(57):363-75. Available from: http://www.scielo.br/pdf/icse/2016nahead/1807-5762-icse-1807-576220150301.pdf

10. Nery IS, Mendonça RCM, Gomes IS, Fernandes ACN, Oliveira DC. Reincidência da gravidez em adolescentes de Teresina, Pl, Brasil. Rev Bras Enferm[Internet]. 2011 [cited 2016 Jun 29];64(1):31-7. Available from: http://dx.doi.org/10.1590/S0034-71672011000100005

11. Jovchelovitch S, Bauer MW. Entrevista narrativa. In: Bauer MW, Gaskell, G. Pesquisa qualitativa com texto, imagem e som: um manual prático. Petrópolis: Vozes; 2011.

12. Germano IMP, Colaço VFR. Abrindo caminho para o futuro: redes de apoio social e resiliência em autobiografias de jovens socioeconomicamente vulneráveis. Estud Psicol [Internet]. 2012 [cited 2014 Apr 10];17(3):381-7. Available from: http://www. scielo.br/pdf/epsic/v17n3/05.pdf

13. Fontanella BJB, Luchesi BM, Saidel MGB, Ricas J, Turato ER, Melo DG. Amostragem em pesquisas qualitativas: proposta de procedimentos para constatar saturação teórica. Cad Saúde Pública[Internet]. 2011[cited 2012 Apr 15];27(2):389-94. Available from: http://dx.doi.org/10.1590/S0102-311X2011000200020

14. Schütze F. Biography analysis on the empirical base of autobiographical narratives: how to analyse autobiographical narrative interviews - part 1. Module B.2.1. Invite: Biographical counseling in rehabilitative vocational training further education curriculum [Internet]. 2007[cited 2012 Apr 15]. Available from: http://www.biographicalcounselling.com/download/B2.1.pdf

15. Unicef. Vivências e relatos sobre a gravidez em adolescentes: uma aproximação aos fatores culturais, sociais e emocionais a partir de um estudo em seis países da região[Internet]. 2014 [cited 2016 Jun 05]. Available from: http://www.unicef.org/lac/UNICEF_PLAN_gravidez_ em_adolescentes_2015.PDF

16. Brasil. Ministério da Saúde. Ministério da Educação. Guia de sugestões de atividades: Semana Saúde na Escola. Tema: Sexualidades e Saúde Reprodutiva[Internet]. 2015 [cited 2015 Mar 01]. Available from: http://bvsms.saude.gov.br/bvs/publicacoes/guia_ sugestoes_atividades_semana_saude_escola_sexualidades_reprodutiva.pdf

17. Costa GPO, Guerra AQS, Araújo ACPF. Conhecimentos, atitudes e práticas sobre contracepção para adolescentes. Rev Pesqui: Cuid Fundam [Internet]. 2016[cited 2016 Oct 15];8(1):3597-608. Available from: https://www.fen.ufg.br/fen_revista/v14/n1/pdf/ v14n1a19.pdf

18. Macedo SRH, Miranda FAN, Júnior JMP, Nóbrega VKM. Adolescência e sexualidade: scripts sexuais a partir das representações sociais. Rev Bras Enferm[Internet]. 2013[cited 2016 Jun 29];66(1):103-9. Available from: http://dx.doi.org/10.1590/S0034-71672013000100016

19. Gondim PS, Souto NF, Moreira CB, Cruz MEC, Caetano FHP, Montesuma FG. Accessibility of adolescents to sources of information on sexual and reproductive health. Rev Bras Cresc Desenvolv Hum [Internet]. 2015 [cited 2016 Jun 16];25(1). Available from: http://pepsic.bvsalud.org/pdf/rbcdh/v25n1/06.pdf

20. Oliveira-Campos M, Nunes ML, Madeira FC, Santos MG, Bregmann SR, Malta DC, et al. Sexual behavior among Brazilian adolescents, National Adolescent School-based Health Survey (PeNSE 2012). Rev Bras Epidemiol [Internet]. 2014 [cited 2016 Jun 16];17(supl.1):116-30. Available from http://www.scielo.br/pdf/rbepid/v17s1/1415-790X-rbepid-17-s1-00116.pdf 